\title{
AN ANCIENT OFFICE FOR HOLY SATURDAY. POSTSCRIPT.
}

THE explanation of an obscure formula which occurs, so far as is known, in only one family of MSS, however justifiable and seemingly necessitated by the context, must often be revised on the discovery of other readings of the same text with different and more definite surroundings. Hence all interpretations of apparently unique passages must necessarily be tentative and provisional. This $I$ had in mind when in the July number of the Journal I offered (p. 607) a 'possible" interpretation of a formula which I believed to be unedited. If the fresh light which I am now able to throw on it leads to the modification or even the rejection of my explanation, I still feel that I was justified in the conclusion I then drew from such evidence as lay before me.

The passage in question Si quis cathecuminus est procedat. Si q.hereticus e.p. Si q. iudeus e.p. Si q. paganus e. p. Si q. arrianus e. p. Cuius cura non est procedat, which in five South Italian MSS comes between the lessons of Holy Saturday and the blessing of the font, seemed so intimately connected with the baptism, confirmation, \&c., administered on that day that I regarded it as being possibly a solemn invitation for these various classes to come forward for these sacraments, interpreting the expression procedat on the analogy of all the texts of the office of the Scrutinium where the invitation to the catechumens to come forward is invariably procedant whilst their dismissal is recedant.

But in the beginning of July when the Journal was on the point of being published, I found that the formula occurs in the Ambrosian antiphoner of the twelfth century, and since then $\mathrm{Mr} \mathrm{H}$. A. Wilson has called my attention to its having been printed from that MS in M. Paul Lejay's article on the Ambrosian rite in the new Dictionnaire d'archeologie chrtienne et de liturgie (fasc. v col. I404). It seemed therefore advisable to re-open the subject as it will be seen that the Milan use differs widely from the Beneventan.'

The formula as it occurs in Ambrosian MSS omits the word est and the clause for the Arian, places the four classes in the order of catechumens, Jews, pagans, and heretics, and has for the final clause invariably Cuius cura non est; Muratori's reading Cui is not justified

1 A short notice by Mgr Magistrett1 'De la missa ou dimissio cathecumenorum, has appeared in the Revue Benédictine (xxil, Oct. 4, 1905) since this postscript was in type. In addition to the Ambrosian use referred to below, he cites for another example of the formula Toması, ed. Vezzosi, viı pp 6 sqq., a twelfth- or thirteenth. century Roman ( ${ }^{2}$ ) sacramentary once at $S$ Maria Maggiore, where it occurs between the procession and the benediction of the font on Easter Even.

VOL. VII. 
by the MS in the Ambrosian Library, and M. Lejay's quotation, besides omitting the first clause has in the last sit instead of est. It is found in the antiphoner (B. M. add. MS 34209 ff. 218,219 , reproduced in the Paleographie Musicale, vol. v) under the heading Sabbato in traditione symboli, preceded by the rubric Finita missa dicat diaconus ex[c]elsa voce and followed by $R$. cum infantibus: Venite filii audite me, timorem domini docebo vos. Mgr Magistretti's Manuale Ambrosianum just published (Milan, 1905) gives (Part ii p. 168) the formula and almost identical rubrics from an eleventh-century Manual.

His edition of the twelfth-century Beroldus (Milan, 1894) gives on p. 94 a more detailed account of the function. 'Sciendum est, quia in traditione symboli omnia tintinnabula sunt sonanda, finita missa, et cuncta ostia claudenda; tamen nullus expellendus, nisi cathecumeni; et presbyter ebdomarius ... retro altare salutat et diaconi ... dicunt has voces: $\mathrm{Si}$ quis cathecumenus procedat, si quis, \&c., et acolythi semper similiter... his dictis cantatur: Venite filii. Deinde archiepiscopus vadit in secretarium ad se parandum, necnon primicerius cum eius lectoribus . . . veniunt tollere licentiam ab archiepiscopo ad aperiendas ianuas pueris ... et tunc aperiunt valvas pueris et dicunt: Ingredimini filii in domum domini. Audite patrem vestrum docentem vos viam scientiae.'

The same account can be seen in the new edition of the Manual on p. 124 of the second part with tunc instead of tamen before nullus nisi catechuminus expellendus; and on pp. 169, 170, where only the words ' $\mathrm{S} 1$ quis catechuminus' are found though they are followed by what is printed as a rubric Seq. al. vox, which probably represents sequitur alia z'ox, unless it be that the copyist did not understand the second si quis. The substance of the above can also be seen in Mabillon Mus. Ital. I ii p. Io, and Muratori Ant. Ital. med. aevi tom iv, col. 842 .

It will be noticed at once that whilst all the Beneventan MSS give the 'Si quis' either before or after the procession to the font on Holy Saturday, the Ambrosian use strictly connects it with the traditio symboli on the preceding Saturday; and although this function is appointed in Roman, Gallican, and Mozarabic sacramentaries for different days towards the end of Lent, it never took place on Easter Even.

As to the meaning of procedere, on which, after all, the whole question hinges, if we had only the first account, we should have to leave it as an ambiguous word, though the immediate sequence in both accounts of 'Venite filii docebo vos' suggests that persons were invited to come forward for instruction; and the longer version is by no means clear, as it seems to involve at least two difficulties: ( $\mathrm{r}$ ) none but catechumens are to be expelled (apparently before the doors are closed), so that if 'si quis' be taken as their expulsion, it would seem that Jews, 
heretics, and pagans, were included in the term, unless we can believe that a primitive formula was retained long after it had become obsolete; and (2) if the pueri who enter are the same as the catechumens who had been dismissed, their procession was first to the outside and then to the inside of the church, and the term procedant could again be regarded as a general one. Nor is this all; the stress laid on the deacon's excelsa voce in all accounts, compared with the leni voce with which we shall see that on another occasion he addresses the catechumens at the chancel gate, renders it possible that in this case they were outside the church or in the narthex, and that he had to raise his voice so as to be heard; if this be so, the order 'procedant' will refer to their entry into the body of the church.

Let us now examine whether the word has a more precise signification when employed in other parts of the Milan use where it is frequently applied to the catechumens during the period of the scrutiny. So far as can be judged from the somewhat involved arrangement of Beroldus and the various MS manuals, it appears in two forms, one at mattins and vespers and the other after the Gospel.

The former can be seen in Beroldus p. 82, in Manuale Ambros. ii p. 122, and in Paleogr. Musicale v p. $15 \mathrm{I}$ of the collotype; every day from the first week of Lent to Palm Sunday, after the psalm Miserere at mattins and also at vespers, the deacon is ordered to sing once or twice (according to the particular week) leni voce: 'Procedant competentes' (or 'catechumini '), after which the doorkeeper (or the acolytes outside the chancel) are to shout out " $\mathrm{Ne}$ quis catechuminus". There is unfortunately no rubric as to what is to happen after this; we have to interpret the order 'Procedant' by what seems to follow immediately after it, viz. ' $\mathrm{Ne}$ quis catechuminus'. If this expressıon is to be taken as the translation of $\mu \eta^{\prime} \tau \iota s \tau \hat{\omega} \nu \kappa a \tau \eta \chi^{o v} \mu \epsilon^{\prime} v \omega \nu$ of the Liturgy of St Chrysostom (ed. Brightman p. 375), it must mean 'Let none remain within'. Otherwise one might argue that the deacon's gentle intimation is addressed to the doorkeeper who in turn bids all the catechumens to enter the church and none to remain outside. The question is further complicated by the distinction " between competentes and catechumini, the former being a class chosen out of the latter as under immediate preparation for baptism; but this distınction does not seem to hold good invariably in the extant Ambrosian liturgica

1 In the missa catechumenorum in the Apostolical Constitutions (Brightman

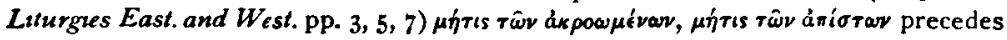

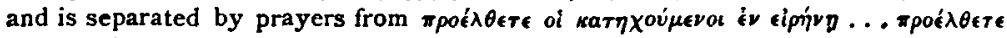

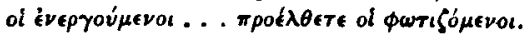

2 This distinction is supported by the statement of St Ambrose (Ep. xx ad Marcellinam \$ 4) that on Palm Sunday 'post lectiones atque tractatum dimissis catechumenis aliquibus competentıbus in baptısterus tradebam basilicae'. 
where we come across the two words as synonymous terms: e.g. Beroldus p. 93, Competentes vadunt ante altare... Orate competentes ... admonendi sunt cathecumeni. . . procedant competentes; and the same persons are called cathecumeni at two scrutinies and competentes at the other two. On the other hand, in the first week (Manual p. I23, Beroldus p. 82), the deacon's 'procedant competentes' is followed by the doorkeeper's 'ne quis catechuminus': which is open to the possible interpretation that the former are to come up whilst the latter have to go out.

When, however, we turn to the office provided for the dismissal after the scrutiny and the signing with the cross which took place after the Gospel, we meet with (Manual p. I 24) 'Procedant competentes, sung by the deacon and repeated by the acolytes, followed by the clear rubric Tunc egrediuntur foras, or, as in another MS, Pueri procedunt. Here at least there seems no room for any doubt; in this case procedant is equivalent to a dismissal.

It remains to be seen whether we must therefore conclude that in the two previous instances it must have had the same meaning. In view of the difficulties already pointed out, I venture to think that the simplest solution is to take the verb in its classical sense like the English 'proceed' as a perfectly general one and that the direction of the procession can only be inferred from the context. If that is so, the formula we are considering may possibly have been used in the Ambrosian service-books as an intimation to the various classes of catechumens ${ }^{1}$ to come forward to be taught the creed. If, however, we admit that it was always a dismissal formula at Milan, it would probably have had that meaning at Benevento, for we know that the Ambrosian use was at least permissible at Monte Cassino until the eleventh or twelfth century and an office of that date for Holy week now in the Vatican library, possibly written for S. Vincenzo di Volturno, further south, provides both the Ambrosian and the current Roman gradual. But, as we now have evidence that Benevento and the South of Italy deliberately added one sentence to the formula and used it for a different service on a different day, we cannot consider it impossible that it may have borne another sense in its changed context.

I am aware that my suggested interpretation does not commend itself to several whose opinion on the matter is of great weight. Mr Brightman, judging by the earliest authorities, St Justin M. and St Cyril of Jerusalem, feels that baptisms must at some time have come after the Gospel, i.e. between the missa catcchumenorum and the missa fidelium, and in that case must have been immediately preceded by a dismissal,

\footnotetext{
- 1 It is not by this suggested that all these classes existed in the twelfth century.
} 
and that when they were separated, the baptisms must have had dismissals of their own. So the Beneventan rite may be a survival of what is generally lost and the Si quis be the dismissal. He suggests that the Coptic dismissal before the consecration of the chrism is a parallel to ours (v. Denzinger Rit. Orient. i p. 250) ${ }^{1}$.

I fully see the force of the parallel which 1 gratefully acknowledge; if $I$ do not think it conclusive, it is due to two facts ( $I$ ) that it necessitates a liturgical distınction between cathecumeni and competentes which is not quite certain, and (2) that the position of the formula in the Bari roll not only after the procession to the font but after the collect Omnip. semp. deus respice propitius ad gentes seems to require the presence and not the absence of the catechumens. The 'Gelasian' rite for Holy Saturday may perhaps help hete: 'Mane reddunt infantes symbolum $^{2}$... Iterum admonentur ab archtdiacono his verbis : catechumeni recedant, omnes catechumeni exeant foras ', i. e. to awalt the hour of Baptism. Is it possible that in South Italy the redditio symboli took place during or after the blessing of the font and that the catechumens were then sent out of the baptistery into an adjoining room for that purpose? We know that later on the clergy were ordered to catechize the children at this point of the service: if some evidence of this practice at Benevento were available, the difficulty would be overcome.

This much at least we may consider as probable, that our formula may have been originally that of the missa catechumenorum and infidelium ", which even in the East was practically disused by the seventh century, and of which we have no trace in the proper place in any Western liturgy: that this formula, with $\pi \rho 0 \epsilon \lambda \theta \in i v$ rendered procedere, was adopted later on for other liturgical uses, e.g. at Milan, for the scrutinium which after the time of St Ambrose was moved from after the Gospel to the end of Mass, and at Benevento for the Holy Saturday baptism between the lessons and the Mass. If in one use the verb signifies dismissal and in the other invitation, it may be due to its being considered a neutral word; possibly at some time this ambiguity was noticed, for in every version of the Roman scrutiny it bears the meaning of coming forward, recedere being used for withdrawal ; e.g. in Ordo Romanus vii (Muratori Mus. Ital. ii pp. 78-82) vocentur infantes

1 The Syrian Jacobite formula for a similar dismissal is also to the point (Denzinger 1i p. 533): 'Abite ii qui dimissi sunt. Exite eac quae dimissae sunt. Nemo catechumenorum, nemo ex energumenis, nemo ex is qui nobiscum orare nequeunt remaneant hic.'

2 For a second redditio symboli on this day in the African Church see Martene De Ant. Eat. Rut. i p. 87.

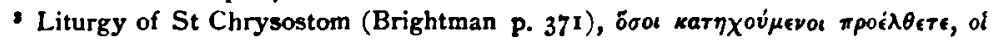

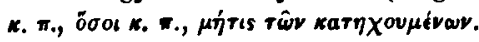


a diacono dicente: Catechumini procedant ... Postea ammonentur a diacono ita: Catechumini recedant. Si quis catechuminus est recedat. Omnes catechumin exeant foras. Et egrediuntur. Exactly the same in the 'Gellone' Sacramentary, the Poitiers Pontifical, \&c., quoted by Martene (Ant. Eccl. Rtt. i, c. I, art. xii, cols. I00-1 I 2); once accedant is found instead of procedant for the entry, and once only (col. 118) procedant for the dismissal. The Rheims Sacramentary (ed. Chevalier pp. 346-35 I) bears the same witness ${ }^{1}$.

The question then cannot as yet be regarded as settled; should it eventually be proved that our formula here as elsewhere is the original missa catechumenorum, we shall not regret the present discussion in our joy at the discovery of a long-lost office. In any case it is a point gained to have been able to couple together the southern with the northern Italian rites and to have added another link to the chain of evidence which is gradually bringing to light the original Roman rite.

H. M. Bannister.

\section{CURRENT MUHAMMADAN TEACHING AS TO THE GOSPELS.}

THE following is a translation, slightly abbreviated, of the Life of Hazrat'Isa (Jesus), written by a Maulawi of literary repute in Delhi. The teaching contained in it would be that given to orthodox Muhammadans to-day in the North of India.

'Muhammadans acknowledge that Hazrat 'Isa was a great Prophet, and believe that Hazrat Mariam was free from sin and chosen of God, and that the birth of Hazrat 'Isa was not without miracle. For this matter is narrated at length in the Quran.

'The people of Islam do not only believe those miracles which are

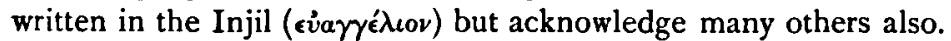

'Hazrat 'Isa was born at Bait-ul-Lahm, which is a village near Baitul-muqaddas (Jerusalem). Hazrat Mariam was at first anxious as to what answer she should give, if people should ask her about her child. It came to pass that the people of her tribe, looking for her, came to her and asked her " $\mathrm{O}$ sister of Harun (Aaron), what have you done, and from whence have you brought this child?"

\footnotetext{
${ }^{1}$ It is again necessary to call attention to Chevalier's editing-on p. $35 \mathrm{I}$ secedat is probably an error for recedat, and the ommes catecumini exeant foras which he prints as a rubric is undoubtedly the third clause of the dismissal formula.
} him."

'Hazrat Mariam pointed to Hazrat 'Isa, and said, "Enquire from 